\title{
Identification Elements of Optimal Organisational Model of Tourism Education in Slovenia
}

\author{
Marija Ovsenik \\ Inštitut za management, Ulica bratov Škofov 12, 1000 Ljubljana, Slovenija, mara.ovsenik@gmail.com
}

\begin{abstract}
The main aim of the research was to identify the elements of a suitable organisational educational model for tourism in Slovenia. Our research was based on the need of inner circular reflexive performance of the individual in the tourism education model, institutionalised concept of education, which is viewed by outer reflexive model of tourism educational institutions performance and functional practical interaction of individuals and tourism institutions at the development of innovative potentials in the field of tourism. Tendencies to develop complex and qualitative services coming from permanent strengthening of innovative potential of tourism services are common in this field. It is necessary to develop a suitable model in the field of tourism education that places an individual in the educational process taking into account his/her conscious reflection, rational reflection and acquired motivation for solving complex projects in various levels of tourism.

Suitable tourism education model, which is level-structured, is expanded in two ways. It includes the active role of an individual in rationalising practical knowledge and strengthening the innovative potential in developing his/her competences, and the role of tourism education institutions. The organisational cultural dimension can be observed as dual activity structure distinguishing between conscious reflection of the external environment on the level of educational institution and internal practical consciousness on the level of individual development of competences. Giddens structuration theory is used as a conceptual frame explaining the organisational-cultural dimensions of suitably structured educational model for tourism in Slovenia.

The conclusion is based on the fact that an individual does not acknowledge the multilevel structure of study at higher education where there is an absence of conscious, practical and motivational reflection. Organisational cultural environment in the field of tourism education in Slovenia prefers practical and functional ways of acquiring competences on a higher and postgraduate (Master's) level of study. Due to the structured changes implemented by the Bologna process, competences are not realised on the higher education level but on the postgraduate (Master's) level, which demands a systematic review and a suitable education model change.
\end{abstract}

Key words: structure, education, reflection, competences, tourism, Slovenia.

\section{Introduction}

Tourism education has a special role in the process of changes. Its role is to change knowledge that directs the operation of tourism systems. The latter is possible only if tourism education programs follow changes and try to grasp them by new transmitting knowledge to pupils and students. Osman-Gani (2004, p. 282) proves the need for continuing education and claims that Far East countries, where tourism develops quickly, stress the education and development of human potentials. The results of ESC (Economic Social Commission) research show that the network of qualitative education institutions, developing new methods and methodological tools, is needed for tourism prosperity.

The tendencies for change in the educational institutions have grown due to the Bologna process in Europe. The implementation of change is challenged by legislation and factual educational processes (Medveš et al., 2008). The functional complexity of the European educational system presents the first problem, the economic crisis endangering the implementation of the Bologna process (EHEA, 2012, p. 28) the second.

Initial desires to design a harmonised European Higher Education were followed by European political and economic tendencies, which deliberately or unintentionally change

Received: $11^{\text {th }}$ March 2013; revised: $27^{\text {th }}$ June 2013; accepted $11^{\text {th }}$ July 2013 
the path of education planning by changing the educational systems from outside (Markelj, 2006, p. 113). The generally accepted common rules on course design are being ignored. The latter influences and decreases university autonomy i.e. diminishes the autonomy of education subsystems. The external pressure, which influences Europeisation of higher education, is a consequence of rational and institutional approach to education that neglects the dynamics of educational environment, which changes quickly and accordingly to changes on a national and especially global level.

The Bologna process is contradictory. European countries understand and implement it differently into its own educational process (Kwiek, 2004, p. 770). Problems often arise from misunderstanding the general principle on a national and European level. The idea of universal implementation of the Bologna process is in a way naïve and optimistic as various cultural, economic, social, demographic and environmental conditions do not make that possible.

EHEA (2012, p. 52) claims that the adaptation of universities, which form the structure of educational subsystem on a national level, is difficult because national countries propose deep education cuts and force universities into seeking funding elsewhere. There is a serious danger of functional and managerial approaches simplifying educational programs and thus diminishing opportunities for educational structures functioning on the conceptual level. Useful competences will diminish students' abilities for functioning and gaining competences on a more comprehensive and conceptual level. In a long run this may lead to reduction of comprehensive knowledge and competitive ability of a social system on a national level. The damage done by the Bologna process might thus be irreversible.

On the other hand some research results show (Ovsenik R., 2007, p. 132) that the level of education, as one of the criterion of excellence of employees in tourism in post socialist countries, is on extremely low, which disables the exploitation of opportunities and suitable responses to changed business conditions on the international tourist market. Such condition derives from the current state of tourism education, which is not well adjusted to knowledge need in tourism. The employment of highly educated people possessing the right competences in tourism is more of an exception. Such condition blocks the development of tourism, which is permanently changing and offering more complex services to please the needs of modern consumers of tourist services. It is true for tourism systems that the management of changes is vital for survival, growth and development, but they do not show any particular interest for educational programs in this field. Usually tourism systems take part in planning the educational programs only on a principal level and give only verbal support.

The transfer of knowledge from tourism to educational organisations and vice versa is almost absent in the process. There are no mentors for practical training in tourism educational organisations. Tourism faces similar problems when planning new tourism educational programs (Ovsenik R., 2006, p. 5). Program updates, content and method of realisation basically do not change. Programs are rarely designed in a way that they coincide with the economic needs and the development of a specific area of expertise. The conditions are not any better on the postgraduate level. The difficulties, which are a consequence of partial structure of tourism educational institutions, are the basis of elements identification of suitable tourism education model, which will make conscious reflection possible in tourism education, rational-practical educational model design and thus encourage external structural motivation of educational organisations and participants to achieve excellence in the field of tourism. Identification model elements will simultaneously allow the possibilities for designing the level structure of tourism educational programs.

\section{Conscious Reflection of Tourism Environment}

Occupational Outlook Handbook (http://www.bls.gov/ooh/, 2012) expects a strong growth of educational services in $21^{\mathrm{st}}$ century. Poslad et al. (1999, p. 1) note that tourism is undergoing the important changes and facing new challenges, which are developing new perspectives on the functioning of tourism systems. Tourism is also experiencing structural and paradigmatic changes that have a significant impact on the development of regional tourism policies and strategies.

In the field of tourism education there is still no real willingness to undertake training, which begins with the introduction of practical knowledge in the educational process in which this knowledge is supplemented on a conceptual level, and then returned to a specific economic environment (Ovsenik, R., 2002).

Tourism systems survive only if they reinforce their selfproductive and self-performed power (Fayos-Solá, 1996). In the systemic sense, the tourism systems need to enhance the integrity and dynamic complexity of their operations. Therefore, the intellectual capital plays an important role in the field of tourism. Despite growing awareness of tourism industry about the importance of qualified workforce for providing quality services to consumers, mobility and promotion, a significant part of the employers do not want to invest in human capital. They cut down the labour costs and employ cheap labour and thus reduce the quality of services. All this affects the cooperation between tourism industry and educational institutions.

The success of education ensures the consistency of development trends in tourism with tourism knowledge and tourism programs that provide such knowledge (Tribe, 2001, p. 440). According to Airey in Tribe (2005) the problem is that most of the tourism courses are designed by the teachers. Tourism industry usually does not cooperate in the process. Haywood in Maki (1992, p. 172) share the same opinion that the participation of the tourism industry in the preparation of curricula is modest. Sheldon et al. (2011) claim that educational institutions must be able to detect and follow the knowledge needs of companies at the right time. The flow of information and knowledge between educational institutions and economy is according to the overall assessment on a low level. Thus the education should not follow the economy needs but a direct transfer of knowledge from the study process into practice and back to the study and the research process that 
creates the added value (Ovsenik, \& Ovsenik, 2008, p. 40). This way we could innovate the knowledge and contribute to the development of educational structures.

The study (Airey and Johnson, 1999) has shown that educational programs pursue "professional liberalism", which combines academic and vocational aspects. Ambrož (2004) has described them as an aggregate approach to education, whose starting point is to provide knowledge and skills that will enable the graduate employability. Integration of both types of knowledge (academic and practical) in the future, is essential for the development of different learning paradigms. We need a shift from a passive role of an individual into a responsible one, because of his/her own learning and professional development that is consistent with his/her maturity, knowledge, skills and experience.

Knowledge development in tourism in Slovenia has in the educational programs as important role as useful knowledge, which can be immediately and directly used. The thought that the traditional academic knowledge as a general criterion for the development of skills and as a prerequisite for business success in the professional field, still dominates. Due to general pressure of the user's knowledge economy, higher education institutions particularly emphasize useful knowledge and skills. On the contrary, the university teachers have a different view as well as different realistic possibilities for carrying out such a course, especially because the academic knowledge in educational, scientific and research environments has a much better image than useful, profession-oriented knowledge. Lack of teachers who have applied knowledge in the field of tourism, often determines the nature of knowledge given to students by their teacher. It is very likely that course designers do not well know the needs of the companies in the field of tourism. The needs for specific skills are dynamically changing. Especially those higher education institutions that are not directly involved in the business processes of companies cannot keep up with these changes. Despite the fact that most of the short-term and long-term documents in the field of higher education reflect the need for participation of companies in the planning process, execution and continuous improvement of programs, there is no real cooperation among them. Situation in the field of education at this time supports the trend towards the development of academic skills in conflict with practical, skills-oriented profession. Situation in the field of education currently supports the trend towards the development of academic knowledge in contrary with practical, professionoriented knowledge.

\section{Factors of Educational Model for Tourism}

Renovation of programs, in the sense of duality of Slovenian tourism education, raises a number of dilemmas. One of the central is the question of the company as that factor of interactions with the environment which provides adequate transfer of knowledge into practice and from practice back to the conceptual sphere, and on the other hand contributes to the self-organised individual, who is determined by the attitude towards the environment.
To identify the elements of optimal organisational model of tourism education in Slovenia we use Giddens structuration theory (Giddens, 1984, p. 5), which determines how to interact with the environment. Since it is a level-structured educational process where the structures must be distinguished from each other and from other structures and the environment, Giddens structuration theory is appropriate. Without proper distinction, individual levels do not produce differing competences. This way they deny their existence. Bologna reform emanates from the importance of the distinction between structures, where they should be identifiable, levels clearly structured, and as such the product of interaction with the environmental needs. The process is thus becoming interactive and permanent.

Giddens structural model is based on the interaction with the environment and provides an open structure allowing the flow of knowledge and information, and adapting to the needs of the environment. Thus the individual understands the conceptual and practical models. The programs that differ in both, conceptual as well as empirical part can ensure reflexivity of knowledge. The individual continually reviews the adequacy of competences in the sense of environmental demands. Reflexivity also relates to the acquisition of practical skills, since they contribute to the competences of individuals, which provide a useful value and the ability to use projectbased approach at individual skill levels. Suitable educational model for tourism guarantees that the individual adds a new value. He/she acquires competences transferred to the project space as innovation in all five stages/levels of organisational model: secondary, post-secondary, higher education, master's and doctoral level.

Programs, classified according to the level of institutions implementing the program, must as a basis have a clear recognisability of levels. If the principles of the Bologna reform work, the conceptual knowledge refines with experiential knowledge at the appropriate level, and produce competences adequate to the level of education and environmental needs. If it is only about simplifying the programs (and their reduction), and practical skills remain a matter of declarative interpretation, the Bologna reform failed to achieve its purpose. The model of the Bologna reform should contribute to the development of competences of individuals, which are transferable to the environment and also allow continuous, independent coordination and innovation.

\section{Purpose and Objective of Research and Hypotheses}

The main objective of the research is to identify the elements of a suitable organisational education model for tourism in Slovenia, which can directly contribute to the development of specific and general competences of students at all levels of education and thus also to competitive abilities of tourism industry in Slovenia. We formed the following working hypotheses:

Hypothesis 1: A suitable tourism educational model reflexively accompanies changes in internal and external tourism environment and responds to them effectively. 
Hypothesis 2: A suitable tourism educational system rationalises its function by creating practical knowledge for tourism needs.

Hypothesis 3: A suitable tourism educational system motivates individuals to use their knowledge in tourism actively and innovatively.

Hypothesis 4: A suitable tourism educational system functions level inclusively.

\section{Structural approach to education}

Knowledge is the primary driver of economic and social development. In order to cope with social action in the knowledge society, the educational subsystem that allows reflexive monitoring, rationalisation of practical knowledge and raises motivation for applying that knowledge in a particular social environment is of great importance. Educational subsystems have in all societies in the past been the focus of various social structures that have been changed, transformed, phased out and re-established in accordance with the current societal views and needs. In the twenty-first century we are facing new approaches to teaching and learning. Among the first to move away from the major theories of education was Rorty (1982), one of the constructivists. He argued that learning is an active, constructive process. The learner in the learning process is the creator of information. After Rorty (1982) people actively create their own subjective interpretation of objective reality. New information is always related to prior knowledge, thus mental performance is always subjective.

An important role in postmodern pedagogy has also Lyotard (1984, p. 47), who was convinced that knowledge is created and will be created in order to sell. Nuyen (2005, p. 93) rejects his vision for the future by claiming that a teacher should not teach a student general skills, but should be his/ her role model inspiring and encouraging him/her to reach a higher level of creativity and imagination. In doing so, the new information and communication technology can be of a great help (Zepp 2005, p. 105).

Students will need to be trained to learn from the emerging future, which is according to Senge (2008, p. 46), no longer a science fiction. Increasingly dynamic business environment is creating common situations when you are no longer able to learn from past experience, because you should be looking for answers to the challenges that have not happened yet. Knowledge creation is a complex multi-level process that has its limitations. Duality of educational structure makes us realise that there are different facets of a single central question about how to produce a suitable educational system, contained in a memory trace of individuals, enabling them to actively learn and have effective interaction with the environment. An important role is played by the excellence of educational institutions. The quality of education and training is a major challenge for researchers, practitioners and educational organisations.

Giddens (1984, p. 7) sees the ability as a necessary part of a special knowledge acquired by an individual or organisation. Capable people are aware of their knowledge and have the confidence to use it in different contexts. In addition, they have the ability to develop this knowledge even after finishing their formal education. We are talking about the competence of human resources; competences are the knowledge, skills and abilities to function effectively in uncertain and changing circumstances on the basis of our own judgement and in an ethical manner. Competences are developed at the appropriate educational environment. The starting point for the implementation of changes in the organisation should be in the change of organisational culture. The concept of "culture" describes a wide margin impact on how people behave in organisations, social communities and national communities.

Organisational culture in educational organisations has a dominant influence on their efficiency and effectiveness (Baldridge, Deal and Ancelle, 1975).

\section{Research Methods}

The purpose of a research was to develop a tool for the analysis of organisational culture and competences and skills of graduates in three steps. First, we created a set of arguments based on literature analysis, and then we collected the data we have obtained from 165 respondents, based on which we carried out the factor analysis - the principal component analysis. In the third step we eliminated the questionnaires that did not fit and used 149 left for testing of the model by means of regression analysis.

\subsection{Instruments and Sample}

The questionnaire consisted of three parts. First part comprised thirty-two variables describing the organisational culture of educational institution dimensions: (1) inclusion, (2) mobility, (3) expertise, (4) employability. The second part comprised nine variables describing the tourism skills and competences. The third part comprised demographic variables: gender, status, tourism educational program. The fourth part included questions: (1) How many invited experts from tourist organisations lectured in your course last year? (2) What is the percentage of mentoring in the learning process in your institution? (3) What is the percentage of available e-learning materials?

Respondents' gender has asymmetrical distribution of $30 \%$ males and $70 \%$ females. This is a typical gender distribution of population in tourism educational programs in Slovenia, where the labour characteristics of the tourism and hospitality industry reflect the international trend of hospitality being considered a rather feminine economic activity. In the structure, there are $20 \%$ respondents from a master program, $14 \%$ respondents from accredited school, $25 \%$ respondents from college, and $41 \%$ respondents from high school.

\section{Factor analysis of observations}

Factor analysis of observations is trying to simplify the complexity of the relationships between the multitude of observed variables, dimensions, or disclosure of joint factors that provide insight into the underlying structure of the data. 
Our research data were analysed by using factor analysis - the method of principal components. Our aim was to reduce the number of variables and create new latent variables, which can be then further explained in the analysis. We were trying to find a new set of variables, the number of which will be lower than the measured variables and represent what is common to the observed variables. The factor analysis tried to reveal the factors, which would explain the dimensions of organisational culture of tourism educational institutions participating in the survey. We used data for measuring dimensions of organisational culture (Table 1).

We have found that the R2 (the coefficient of determination R2 measuring the power relationship between the two variables) is greater than 0.20 in all variables, which is the first indication that the factor analysis of the variables in the model can be carried out successfully. Adequacy of the data for factor analysis was tested by Kaiser-Meyer Olkintestom (KMO) and Bartlett's test. This tests the correlation matrix of a unit. The higher the rate of KMO test, more data are suitable for analysis. If the rate of KMO is greater than 0.8 , which is in our case the calculation $(\mathrm{KMO}=0.804)$, the optimal adequacy of the data can be used.

The variables in constant factor matrix are not distributed sufficiently among factors. Therefore, the factor matrix was rotated using Varimax normalized rotation method. Rotated matrix has given satisfactory results. Variables with a correlation lower than 0.39 were excluded from the analysis.

The reliability test with Cronbach's alpha test showed that the most appropriate factor structure, which consists of five latent factors, adequately describing the dimensions of organisational culture, educational institutions and together explains $46.19 \%$ of the variance. We researched the organisational culture in educational institutions on secondary, post secondary, higher education and postgraduate level.

The first factor "Participation" (see Table 2) explains the most variance, $23.227 \%$, and confirms ten statements. "Cooperative communication among teachers, administrative staff and students" (0.690) explains the highest variance in the factor.

Involvement is the dimension of organisational culture, which includes central beliefs, values and norms of educational institutions. If pupils and students do not perceive their active role in the educational process, discrepancy with their own self-esteem might occur. The analysis of the dimensions suggests that respondents from tourism educational institutions place the greatest emphasis on the cooperative communication between teachers and pupils or students. In this process the educational institution actively communicates their values, beliefs and norms in the educational process.
It is particularly important that it communicates with all internal and external participants and equally includes them in the educational process, in its reform and continuous improvement of educational programs and thus also in the design of specific and general competences of students. The involvement of students in the educational process is supported by excellent teachers, qualitative educational programs and the support of programs with new information technologies. The active involvement of students is also supported with educational institutions activities, promoting the development of self-organisation and self-help of pupils and students in the educational process, the introduction of best practices, case studies and team work in a favourable environment among pupils, students and teachers.

The central assumption of the involvement of all participants in the educational process is that an organisation must constantly maintain equality in the educational approach, transmit common values, beliefs and norms to all participants in the educational process and encourage the participation of all participants. If the educational organisation is not efficient enough, obstacles of the educational process may occur. They are reflected in the incomplete conscious reflection of the internal and external environment that is in complete selfevaluation and external evaluation of educational programs.

The second factor "Competency" (see Table 2) explains a slightly lower variance, i.e. $7.936 \%$ and confirms five statements. Most of the variance in the factor is explained with the statement: "The ability to research, application of research procedures and processes in marketing" (-0.729).

The second factor in the analysis has a negative sign, which means that it has its own meaning within the factor model. The latter is particularly expressed in the research, the use of independent research procedures and processes in marketing and research methods management, procedures and processes in the process of reflection of internal and external environment. The ability of anticipating problem solving contributes to conscious reflection in professional ethics. Conscious reflective functioning of the education program is possible with continuous, independent, active and ethical action in tourism education. New knowledge acquisition in the educational program is based on qualitative research process developing responsible and independent research on all levels, which is the result of conscious reflective observation of the environment.

The third factor "Comparison" (see Table 2) explains even less variance $(5.996 \%)$ and confirms seven statements. Maximum variance in the factor is explained with the statement: "Educates professionals, whose expertise is comparable

Table 1: Appropriateness of factor analysis

\begin{tabular}{lll}
\hline Test & Parameter & Value \\
\hline Kaiser-Meyer-Olkin Measure of Sampling Adequacy & &, 804 \\
Bartlett's Test of Sphericity & approximation of chi-square & 1368,032 \\
& difference & 406 \\
& statistical significance &, 000 \\
\hline
\end{tabular}


Table 2: Factor analysis - method of principal components

\begin{tabular}{|c|c|c|c|c|c|c|}
\hline Code & Claims & $\mathrm{F} 1$ & $\mathrm{~F} 2$ & F3 & $\mathrm{F} 4$ & F5 \\
\hline & INCLUSION & & & & & \\
\hline $\mathrm{P} 1$ & Dynamic learning process supported by ICT & 0,562 & 0,045 & $-0,021$ & 0,036 & 0,247 \\
\hline $\mathrm{P} 2$ & Continuous renewal of curricula & 0,660 & 0,040 & 0,016 & 0,081 & 0,323 \\
\hline P3 & Consistency in the curricula and equalization with technology & 0,587 & 0,127 & 0,182 & 0,164 & 0,308 \\
\hline P4 & Tutors' assistance and advice to students & 0,507 & $-0,141$ & 0,005 & 0,294 & 0,262 \\
\hline P8 & Use of best practices and case studies & 0,499 & 0,233 & 0,154 & 0,190 & 0,146 \\
\hline $\mathrm{P} 10$ & Promotes new forms of self-organization and student self-help & 0,524 & 0,014 & 0,373 & 0,072 & 0,147 \\
\hline P16 & Effectively develops general and specific students' competences & 0,605 & 0,177 & 0,303 & 0,065 & 0,025 \\
\hline $\mathrm{P} 21$ & Has highly qualified and motivated teachers and administrative stuff & 0,593 & 0,253 & 0,207 & $-0,100$ & 0,100 \\
\hline $\mathrm{P} 22$ & Provides a favourable relation between the number of students and teachers & 0,402 & 0,178 & 0,365 & $-0,177$ & 0,022 \\
\hline $\mathrm{P} 23$ & $\begin{array}{l}\text { Provides a cooperative communication among teachers, administrative stuff } \\
\text { and students }\end{array}$ & 0,690 & 0,133 & 0,219 & $-0,032$ & 0,083 \\
\hline
\end{tabular}

\section{COMPETENCY}

KD Competences providing autonomy at professional work and decision mak- $-0,126 \quad-0,688 \quad-0,181 \quad 0,050 \quad 0,086$ ing

KE Ability to analyse, synthesize and predict solutions and factors resulting in $-0,133-0,597$ international and domestic/national tourism

KF Development of ethical reflection and commitment to professional ethics

$$
-0,275-0,569
$$

$0,009-0,729$

$\begin{array}{lll}-0,019 & 0,253 & 0,015\end{array}$

KG Ability to research, use of research methods and processes in marketing

$-0,073-0,635$

$0,012-0,118-0,159$

$\mathrm{KH}$ Management of research methods, procedures and processes

$0,117 \quad-0,078-0,167$

\section{COMPARABILITY} ism

P25 Uses methods for measuring and knowledge monitoring of employees in $0,028 \quad-0,014$
educational institution and structural knowledge of organisation

P26 Reputation ranking (by the model of marketing school home page) in the $0,214-0,091$
environment and expressing concern regarding the image

P27 Consistent with global, regional, and local trends of tourism development $0,266 \quad 0,158$ and all changes in tourism

P28 Educates professionals whose knowledge is comparable with the knowledge 0,246 0,204 of experts from different tourism educational institutions

P17 Enables students cooperation in various tourist/culinary events

P20 Pays attention to students' identification and evaluation of achievements

$$
-0,133-0,028
$$

0,447

$0,371-0,029$

0,436

$-0,160 \quad 0,335$

\section{PRACTICAL KNOWLEDGE}

P5 Has a developed system of practical training and education in and out of $0,290-0,068$
the institution

P6 Makes sure that students have frequent enough consultations with teacher at $0,049 \quad 0,151$ school and during professional practice

$-0,065 \quad 0,667 \quad 0,019$

$0,190 \quad 0,615 \quad 0,174$

\section{INNOVATION}

P 13 Enables the development of business ideas in business incubator (own and $0,278 \quad 0,206 \quad 0,304 \quad-0,076 \quad 0,609$ foreign)

$\begin{array}{lllllll}\text { P } 29 & \text { Organises events intended for self promotion. } & 0,289 & 0,081 & 0,006 & 0,001 & 0,527\end{array}$

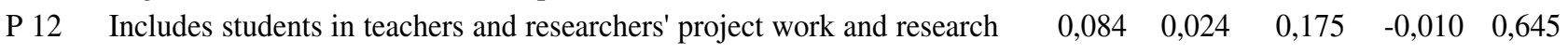

P 14 Enables its students the support of professional career development with its $0,214 \quad 0,073 \quad 0,069 \quad 0,162 \quad 0,162$ career centres

P 15 Has internal labour market

$\begin{array}{lllll}0,265 & -0,234 & 0,010 & 0,145 & 0,400\end{array}$


Table 3: Eigenvalue factor

\begin{tabular}{ccccc}
\hline & Eigenvalue & \% variance & Cumulative eigenvalue & \% cumulative eigenvalue \\
\hline 1 & 6,968 & 23,227 & 6,968 & 23,227 \\
2 & 2,219 & 7,396 & 9,187 & 30,624 \\
3 & 1,799 & 5,996 & 10,986 & 36,620 \\
4 & 1,536 & 5,121 & 12,522 & 41,741 \\
5 & 1,336 & 4,453 & 13,858 & 46,194 \\
\hline
\end{tabular}

to expert knowledge from other educational institutions in tourism" (0.697).

The third factor follows a logical sequence of reflective observation of the internal and external environment and a systematic and independent research of this environment. Education of future professionals, who will have internationally comparable knowledge, is the result of appropriate reflection and new knowledge creation in the educational program. Educational institutions in the survey continuously monitor the performance of their pupils and students in the field of tourism and measure their performance. In doing so, they recognise students' competence compliance with global, regional and national development in tourism.

The fourth factor "Practical knowledge" (see Table 2) explains $5.121 \%$ of the variance and combines three statements. The maximum variance in factor is explained with the statement: "It has developed a system of practical training and education in the institution and outside it" (0.667).

The fourth factor emphasizes the importance of testing practical knowledge in tourism. Educational institutions in our research have a developed system of practical training and education, which covers the internal learning and external business environment. Practical knowledge application, acquired by pupils and students in the educational program, is monitored by the employment possibilities of their graduates in tourism.
The fifth factor "Innovation" (see Table 2) explains $4.453 \%$ of the variance and combines five statements. The maximum variance in the factor is explained by the statement: 'Let's support students' career development with their career center" (0.657).

With the help of eigenvalues, we have found out that the maximum variance in factorial model explains five factors.

\section{Regression Analysis of Educational Model}

We have used a regression analysis for model analysis to determinte how tourism educational institutions work when integerated on a multi-level and according to findings of structural theory based on conscious and practical knowledge reflection and creation of motivational potential to use the knowledge mentioned. Independent, dependent and moderating variables were included in the model.

Independent variables are represented by inclusion, e-materials accessibility, mobility, motivation for the use of practical knowledge and innovation. Dependent variable is represented by excellence competence and moderatating variable is represented by multi-level structured program.

The result of the regeression analysis is positive, independent variables show statistically significant variance in

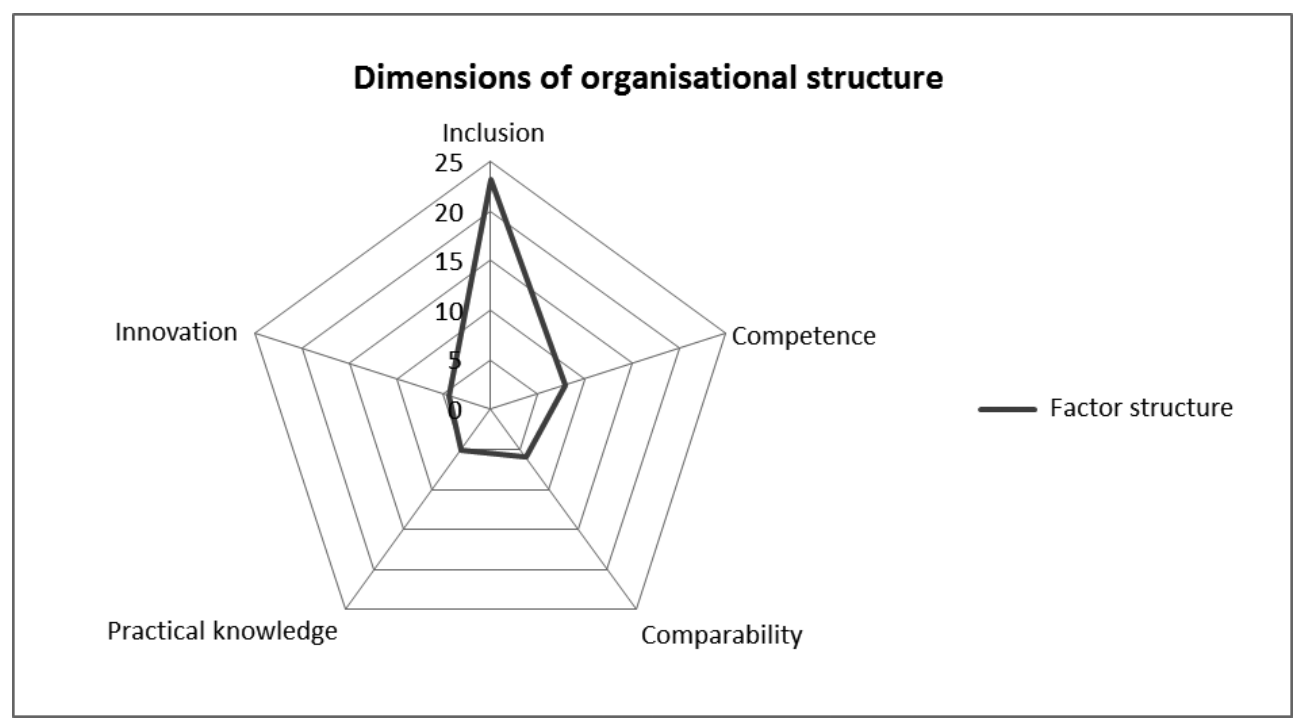

Figure 1: Dimensions of organisational culture 
Table 4: Predictive power of the regression model of program stratification in tourism education

\begin{tabular}{lccccccc}
\hline Dep. var. & Multiple $-\boldsymbol{R}$ & Multiple $-\boldsymbol{R}^{\mathbf{2}}$ & Adjusted $-\boldsymbol{R}^{\mathbf{2}}$ & SS - Residual & df - Residual & $\boldsymbol{F}$ & $\boldsymbol{p}$ \\
\hline KOMP & 0,479 & 0,229 & 0,179 & 9,356 & 154,000 & 4,580 & 0,000 \\
\hline
\end{tabular}

independent variable $\left(R^{2}=0,18 ; p=0,0000 * * *\right) . R^{2}(0,48)$ shows moderate foretold power.

Furthermore, we have tested correlations in the regression model against univariate test (Table 4). The correlation relationship between independent variable Inclusion and dependent variable Competency $(F=12,468 ; p=0,001 *)$ is the strongest and statistically significant. The second strongest is the correlation between independent variable E-materials accessibility and dependent variable Competence $(F=4,144$; $\left.p=0,044^{*}\right)$. A bit weaker is the correlation between independent variable Innovation and dependent variable Competence $\left(F=4,068 ; p=0,045^{*}\right)$. The weakest is the correlation between categorical predicator Program and dependent variable Competence $(F=2,959 ; p=0,087)$, while the independent

Table 5: Univariate test of statistically significance of correlation with dependent variable

\begin{tabular}{lccccc}
\hline & SS & Deviation & MS & $\boldsymbol{F}$ & $\boldsymbol{p}$ \\
\hline Intersection & & 0 & & & \\
Number of experts & 0,000 & 1,000 & 0,000 & 0,008 & 0,930 \\
Status & & 0,000 & & & \\
Distance learning & 0,180 & 1,000 & 0,180 & 2,959 & 0,087 \\
E-materials accessibility & $\mathbf{0 , 2 5 2}$ & $\mathbf{1 , 0 0 0}$ & $\mathbf{0 , 2 5 2}$ & $\mathbf{4 , 1 4 4}$ & $\mathbf{0 , 0 4 4} *$ \\
Inclusion & $\mathbf{0 , 7 5 7}$ & $\mathbf{1 , 0 0 0}$ & $\mathbf{0 , 7 5 7}$ & $\mathbf{1 2 , 4 6 8}$ & $\mathbf{0 , 0 0 1} *$ \\
Comparability & 0,016 & 1,000 & 0,016 & 0,260 & 0,611 \\
Practicality & 0,011 & 1,000 & 0,011 & 0,173 & 0,678 \\
Innovation & $\mathbf{0 , 2 4 7}$ & $\mathbf{1 , 0 0 0}$ & $\mathbf{0 , 2 4 7}$ & $\mathbf{4 , 0 6 8}$ & $\mathbf{0 , 0 4 5} *$ \\
Program & $\mathbf{0 , 4 1 8}$ & $\mathbf{2 , 0 0 0}$ & $\mathbf{0 , 2 0 9}$ & $\mathbf{3 , 4 4 4}$ & $\mathbf{0 , 0 3 4}$ \\
Error & 9,356 & 154,000 & 0,061 & & \\
\hline
\end{tabular}

Standard field of estimation error $=0,246$

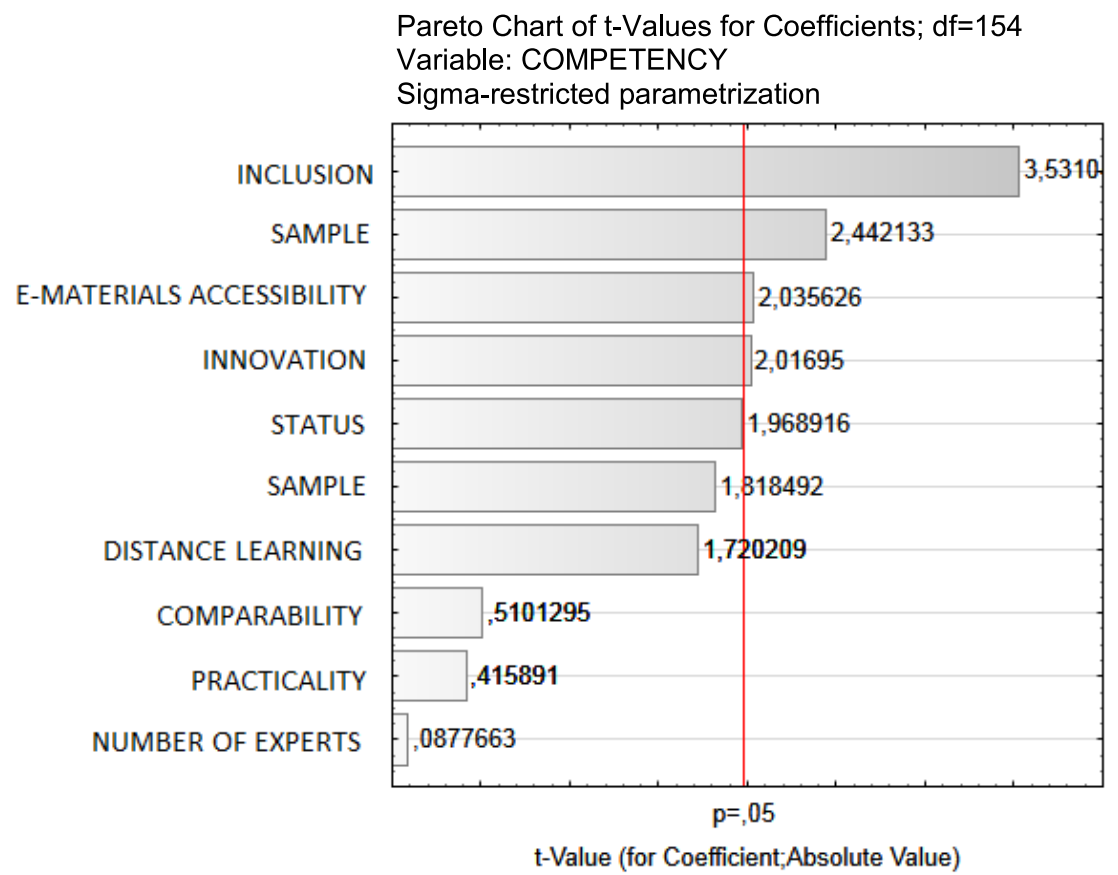

Figure 2: Pareto diagram for $t$ - value of the coefficients 
variables Program comparability and Practicality contribute little to the model and are statistically non significant. The same applies for variable Number of experts.

Figure 2 shows foretold power of individual independent variables within the regression model. Maximum variance is shown by the Inclusion $(t=3,531 ; p=0,05)$ variable. A bit less explanatory is the Vocational College level (sample) $(t=$ 2,442; $p=0,05)$. Pupils and students develop competences most if educational programs reform, change dynamically and if communication is present among participants during the process of program reform. Vocational college educational level contributes most to competence development.

Categorical predicator program is statistically significant correlating to dependent variable Competence. Table 5 shows that maximum variance is in dependent variable Vocational college and (arit. mean $=2,438$; stand. deviation $=0,383$ ) in MSc Tourism (arit. mean $=2,386$; stand. deviation $=0,325$ ). The latter levels have the maximum standard deviation, which points to a bit higher respondents' incosistency.
Statistically significant correlation occurs between levels of educational programs and competence development. Figure 14 shows a covariance among the educational level and dependent variable Competence and independent variables and is statistically significant $(F(2,154)=3,4441 ; p=0,0344)$. The highest competence development is chosen by respondents attending Vocational college.

Figure 3 shows a covariance significant between educational programs and competences; the maximum on post secondary (vocational) level. The lowest covariance is on the secondary educational level. Results show that post secondary students determine strong correlation between the program and competences they experience.

The results of regression analysis further show that maximum model variance explains the post secondary level in categorical predicator Program $\left(\beta=0,462 ; p=0,006^{*}\right)$, followed by independent variable Inclusion, which explains $(\beta=$ $\left.-0,367 ; p=0,001^{*}\right)$, and independent variable Innovation $(\beta=$ 0,$\left.196 ; p=0,045^{*}\right)$.

Table 6: Descriptive statistics by levels of factors (categorical variable) for dependent variable Competency

\begin{tabular}{llcccccc}
\hline & Factor level & N & Arithmetic mean & Standard deviation & Standard error & $\mathbf{- 9 5 , 0 0 \%}$ & $\mathbf{+ 9 5 , 0 0 \%}$ \\
\hline Total & & 163 & 2,293 & 0,255 & 0,020 & 2,254 & 2,333 \\
\hline Program & MSc Tourism & 29 & 2,386 & 0,325 & 0,060 & 2,263 & 2,510 \\
Program & Vocational College Tourism & 21 & 2,438 & 0,383 & 0,084 & 2,264 & 2,612 \\
Program & Professional College Tourism & 37 & 2,301 & 0,262 & 0,043 & 2,214 & 2,389 \\
Program & Tourist Technician & 76 & 2,214 & 0,118 & 0,014 & 2,187 & 2,241 \\
\hline
\end{tabular}

SAMPLE; LS Means

Current effect: $F(2,154)=3,4441, p=, 03441$

(Computed for covariates at their means)

Vertical bars denote 0,95 confidence intervals

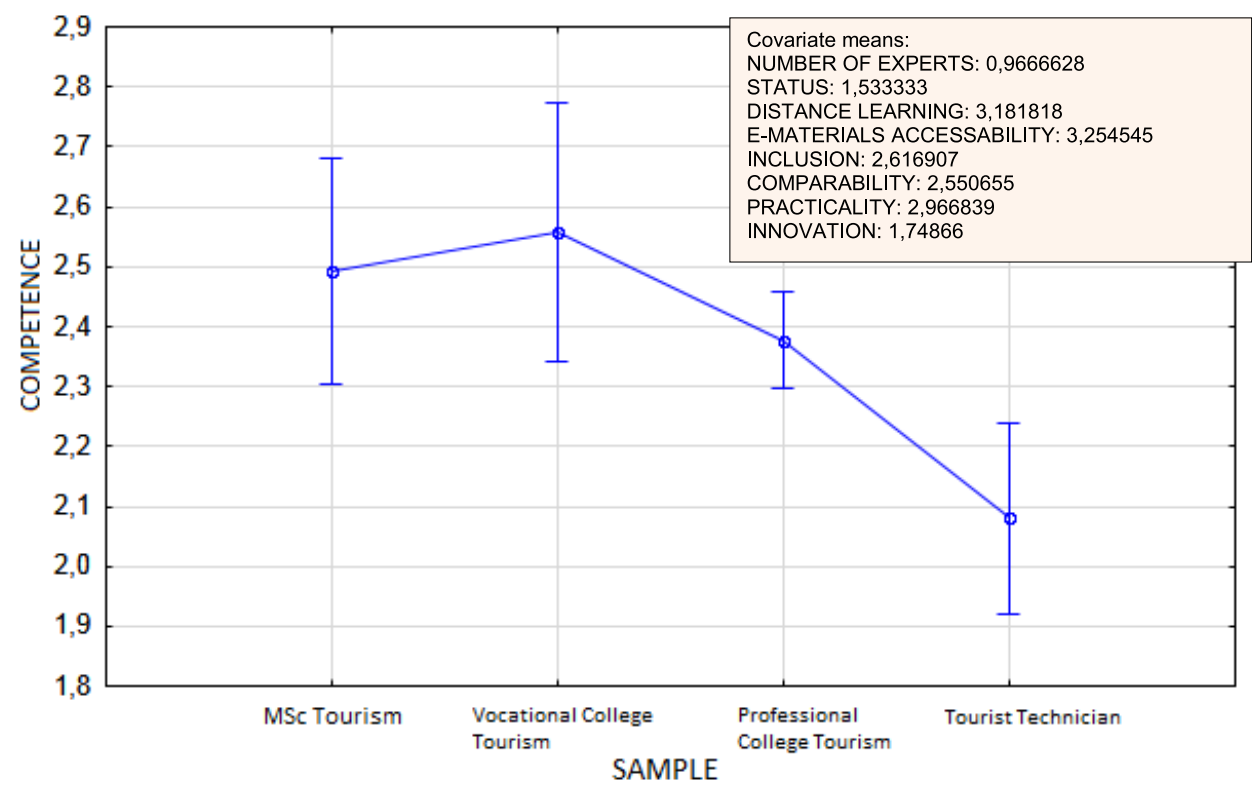

Figure 3: Arithmetic covariance between levels of categorical predictor and dependent variance 
Results show that post secondary level is the most structured level in the model due to strong link to competence development. Based on the results, one can conclude that the program gives direct insight into competence development known to the survey participants. The variable Inclusion is important as its correlation to the competence development is negative. The result may be explained as respondents' need to directly co-create educational program according to their knowledge and the need to develop certain competences. Overview of independent variables tolerance presents a heterogeneous image. Tolerance is marked 1 minus square multiple correlation variable with all other independent variables in the regression equation. Lesser tolerance means little variable contribution to the regression model. Independent variable status in the educational program (pupil/student) and all categorical predicator Program levels contribute the least to our equation. The tolerance in all the other variables is normal indicating the relationship between them and other independent variables low multi-linear.

\section{The Confirmation of the Hypotheses}

Hypothesis 1: Conclusions of the empirical analysis of the competence model confirm a hypothesis that a suitable tourism educational model reflexively accompanies changes in internal and external tourism environment and responds to them effectively. A suitable educational model creates rational knowledge working on the principle of circularity when interacting with internal and external environment. Results of the regression analysis confirm the hypothesis that pupils and students of tourism have the ability of inner reflection and that suitable educational program provides effective conscious external tourism environment reflection. In doing so it provides conditions for rational knowledge reflection in terms of individual's competences.

Hypothesis 2: Suitable tourism educational system rationalises its function by creating practical knowledge for tourism. It uses various sources from external and internal environment classifying them systematically thus providing their direct access. This system functions routinely, dynamically and responsively to external and internal environment of an individual, who is included in the competence system. Qualitative competence system operates on the basis of practical consciousness using long term consciousness including previous individual's memory traces. The hypothesis can be confirmed according to the regression analysis results.

Hypothesis 3: Suitable tourism educational system motivates individuals to use their knowledge on tourism actively and innovatively. The hypothesis is confirmed as results show that the competence development, which is motivationally sufficient, is both rational and conscious. The results assume that those individuals who have excellent competences develop their own motivational potential, which does not need to be encouraged by environment changes. An individual, who knows what s/he does and is aware of his/her potentials and competences, is capable of functioning in complex and level structured projects and establishing effective interaction with others and tourism structures.
Hypothesis 4: The hypothesis that a suitable tourism educational system functions level inclusively can be confirmed as results on the empirical level, i.e. post secondary and postgraduate (Master's) level, confirm individual's ability to rationalise his/her knowledge. The absence of other levels in the model shows that present model does not enable knowledge rationalisation on all levels. The latter can be linked to insufficient level structure and means of employment in tourism. Employers are known for employing people with lower educational levels. They do not show any interest in employing highly qualified workers.

\section{Discussion}

The research shows the meaning of tourism educational models' suitability, actual educational dimension and the roles of individuals and educational institutions in educational process. In modern educational systems, based on the Bologna Process, competence is accepted as legitimate and professional basis for valuing and developing educational programs. The same applies for tourism.

The competence model is used for orientation of human resources on the labour market. Social circumstances have established the concept of competence based on memory traces, accounting for the role of educational institutions in circular movement producing knowledge and individual's active role. The prevailing recognition is that a diminished role of educational institutions or tourism decreases the role and effectiveness of educational systems and competences of graduates. A rational response to both strategies is imperative. The Bologna Process principles bring dual educational system creating useful and structural knowledge. Suitable educational models are a consequence of controversial contradictions among individual's autonomy, his/her inner reflection and other participants in the educational system.

From individual's point of view, a competence model derives from the absence of possible inner individual's reflection according to individual's achievement and independence. Competences, based on qualitative education, should become the main criterion for organisation's success. We need a level structured tourism educational model allowing conscious, rational and motivational reflection on all educational levels to contribute to knowledge rationalisation and making level education possible. The research results show the educational system structure insisting upon multi level educational program, which defines the quality of inter-level learning approach reflecting on individual's competences. Structures, which are competent and excellent, launch the educational process development advancing individual's competence according to the level and ability of problem solving in tourism.

On this level of discussion on the development of suitable tourism educational model, one can talk about the positive components of classical educational model, where all academic institutions have a prevailing role, functional components of educational model, which takes into account dynamic needs of tourism and positive components of inner reflexive model, which takes into account decentralisation, personal values, autonomy and responsibility. 


\section{Final Thought}

Conclusions summarised from the research, refer to the facts that:

- The level structure of educational programs in Slovenia is unclear (only higher education and postgraduate students note a relationship between educational level and competences. As educational programs do not reflect qualitative higher level of competence development, new approaches, which encourage problem solving according to its complexity, must be integrated into education.

- The results of the inclusion level of individuals into the process of conscious reflection show that educational programs do not adapt to environmental needs, global trends and economic needs. We need a shift in the education, change from passive (factual) to active project learning approach, which is based on individual's active cooperation and research. It also promotes additional teacher training.

- There is a positive connection between individual's competence development and subconscious motivation on motivational unconscious level, realised primarily on higher education and postgraduate level. The analysis results show that educational programs encourage competence development only on these two levels.

- We acknowledge a positive connection between active research of environment, which is a basis of adaptation and improvement of educational programs and individual's expectations in the filed of tourism, on the conscious reflexive level manifested by active environment observation.

New educational programs, acquiring competences for effective and successful function in tourism, following the principle of level structure, are still emerging. The study provides some answers on how to help a level structured approach to develop students'skills to enable the efficient and effective functioning of the ascending complex environment. Integrating qualitative and quantitative approach has shown positive results and guidance for further systematic reflective observation of the environment.

The need for more sophisticated methods of research and learning in tourism educational programs indicates the need for development in order to creatively respond to a changing environment. It is possible to achieve competence acquisition for in-depth analysis of the environment, responsiveness to change, and ultimately the autonomy of individuals, which would prove successful for tourism education by providing enough open organisational culture of educational institutions.

\section{Literature}

Ainley, J. (2009). National policies and practices on ICT in education: Australia. In Cross-national information and communication technology: policies and practices in education. Ed. T. Plomp et al., Charlotte, NC: Information Age Publishing, 2009, pp. 67-82.
Airey, D. \& Johnson, S. (1999). The Content of Tourism Degree Courses in the UK. Tourism Management, 20(2), 229-235, http://dx.doi.org/10.1016/S0261-5177(98)00079-X

Airey, D. \& Tribe, J. (2005). An International Handbook of Tourism Education. Riverport: Elsevier.

Ambrož, M. (2007). Pomen inovativne učne kulture v izobraževanju za turizem [The importance of learning culture in tourism education]. In: Ustvarjalna organizacija: zbornik 26. mednarodne konference o razvoju organizacijskih znanosti, [Proceedings of the 26th International Conference on Organizational Science Development], Portorož, Slovenia, March, 28th-30th, 2007, (pp. 93-99). Kranj: Moderna organizacija.

Ambrož, M. (2004). Bolonjski proces in model visokošolskega izobraževanja za turizem [Bologna process and model of tourism education]. In: Proceedings of the 23rd International Scientific Conference on organizational Science Development, Slovenia, Portorož, March, 24th-26th 2004. Management, knowledge and EU. Kranj: Moderna organizacija, pp. 29-35.

Ambrož, M., Ovsenik, R. (2007). Tourist origin and spiritual motives. Management - Journal of contemporary Management Issues, 11(2), 71-86.

Baldridge, J. V., Deal, T. E. \& Ancel, M. Z. (1975). Managing change in educational organizations:sociological perspectives, strategies, and case studies. Berkeley California: McCutchan Publication Corporation.

Bowden, J. \& Marton, F. (1998). The University of Learning: Beyond Quality and Competence in Higher Education. London: Kogan Page Limited.

Boyatzis, R.E. (1982). The Competent Manager: A Model for Effective Performance. New York: John Wiley \& Sons.

Deal, T. E. \& K. D. Peterson (1990). The Principal's Role in Shaping School Culture. Washington, D. C.: Department of Education, Office of Educational Research and Improvement.

Dewey, J. (1980). The School and Society. Carbondale: Southern Illinois University Press.

EHEA. (2012). The European Higher Education Area in 2012: Bologna Process Implementation report. Brussels: Education, Audiovisual and Culture Executive Agency, available at http:// www.ehea.info/Uploads/(1)/Bologna Process Implementation Report.pdf (July5, 2013).

Fayos-Solá, E. (1996). Tourism policy: a midsummer night's dream? Tourism Management. 17(6), 405-412, http://dx.doi. org/10.1016/0261-5177(96)00061-1

Giddens, A. (1984). The constitution of society: Outline of the theory of structuration. Cambridge: Polity Press.

Haywood, K.M. \& Maki, K. (1992). A conceptual model of the education employment interface for the tourism industry. World Travel and Tourism Review, 2, 237-248.

Havelka, D. (2003). Predicting Software Self Efficacy among Business Students: A Preliminary Assessment, Journal of Information Systems Education, 14(2), 145-152, available at: http://jise.org/Volume14/14-2/Pdf/14(2)-145.pdf (July, 12, 2013)

Hillage, J. \& Pollard, E. (1998). Employability: developing a framework for policy analysis. London: Department for Education and Employment, Research Report RR85.

Hsu, C. H. C. (ed.) (2006). Global Tourism Higher Education, Past, Present, and Future. New York: Routledge.

Kreber, C. (2013). Authenticy in and through teaching in higher education. Routledge: New York.

Kwiek, M. (2004). The Emergent European Educational Policies under Scrutiny: the Bologna Process from a Central European perspective. European Educational Research Journal, 3(4), 759776, http://dx.doi.org/10.2304\%2Feerj.2004.3.4.3 
Loukkola, T. \& Zhang, T. (2010). Examinig Quality Culture: Part1 Quality Assurance Processes in Higher Education Institutions. Available at: http://www.eua.be/pubs/Examining_Quality_ Culture_Part_1.pdf (July, 7 2013)

Lyotard, F. (1984). The Postmodern Condition. Manchester: Manchester University Press.

Markelj, N. (2006). Neskladnosti v bolonjskem kurikularnem načrtovanju študijskih programov [Inconsistencies in the Bologna curriculum planning courses]. Sodobna pedagogika, 57(4), 112-130.

Medveš, Z., Kodelja, Z., Mažgon, J., Ermenc, K., S., Peček, M., Lesar, I. \& Pevec G., (2008). Prispevek poklicnega in strokovnega izobraževanja $\mathrm{k}$ pravičnosti in socialni vključenosti [The contribution of vocational training to equity and social inclusion]. Sodobna pedagogika, 59(5), 74-94.

Možina, S. et al. (ed.). (2002). Management: Nova znanja za uspeh [Management: New Skills for Success]. Radovljica: Didakta.

Osman-Gani, AA. M. (2004). Human Capital Development in Singapore: An Analysis of National Policy Perspectives. Advances in Developing Human Resources, 6(3), 276-287, http://dx.doi.org/10.1177\%2F1523422304266074

Ovsenik, M. (2007). Change development and quality of work: basic concepts and dynamics of change. Invited lecture at Göteburgs Universitet, Institutionen för socialt arbete, October 26, 2007.

Ovsenik, J. \& Ovsenik, M. (2013). Organizacija in zavestnost - Ob modelu 'Sinusoida 2000'. [Organization and consciousness The model of Sinusoida]. In: Pametna organizacija: zbornik 32. mednarodne konference o razvoju organizacijskih znanosti, [Smart Organization: Proceedings of the 32nd International Conference on Organizational Science Development], Portorož, Slovenia, March, 20-22, 2013, (pp. 772-779). Kranj: Moderna organizacija.

Ovsenik, R., Kiereta, I. (2006). Destination Management. Peter Lang Publishing, Germany

Ovsenik, R. (2002). Protislovja in perspektive destinacijskega managementa na področju slovenskih Alp [Contradictions and perspectives of destination management in Slovenian Alps], doctoral thesis, University of Maribor.

Poslad, S., Laamanen, H., Malaka, R., Nick, A., Buckles, P., Zipf, A. (1999). Creation of user-friendly mobile services personalised for tourism, EU project CRUMPET. Available at: http://www. elec.qmul.ac.uk/crumpet/docs/papers/3g2001-crumpet.pdf (July 7, 2013)

Rorty, R. (2007). Philosophy as Cultural Politics: Philosophical Papers. Cambridge, Cambridge University Press.

Rosile, G. A. \& Boje, D. M. (1996). Pedagogy for the Postmodern Management Classroom: greenback company. In: Boje D.M. Gephart R.J. \& Thatchenkery (1996). Postmodern Management and Organization Theory, London: Sage.

Senge, P. (1990). The Fifth Discipline: The Art and Practice of the Learning Organization. New York: Doubleday Currency.
Sheldon, P.J., Fesenmaier D.R. \& Tribe, J. (2011). The Tourism Education Futures Initiative (TEFI): Activating Change in Tourism Education. Journal of Teaching in Travel \& Tourism, 11(1), 2-23, http://dx.doi.org/10.1080/15313220.2011.548728

Tkalčič, M. (2009). Vpliv managementa v turističnem gospodarstvu na izobraževanje za turizem: primer Slovenije [The impact of management in the tourism industry in the education of tourism: the case of Slovenia], Doctoral dissertation, University of Primorska, Faculty of Tourism Studies.

Uran, M. \& Ovsenik, R., (2006). Razvojni načrt in usmeritve slovenskega turizma 2007-11. [Development Plan and Policies of Slovenian tourism 2007-11]. Republic Slovenia, Ministry of Economy.

Tribe, J. (2001). Research Paradigms and the Tourism Curriculum. Journal of Travel Research, 39(4), 442-448, http://dx.doi.org/10 $.1177 \% 2 \mathrm{~F} 004728750103900411$

Vengesayi, S. (2003). A conceptual model of tourism destination competitiveness and attractivenes. Australia: Universtiy of South Australia.

Yeoman, I. (2008). Tomorrow's Tourist: Scenarios \& Trends. Oxford: Butterworth Heinemann.

Zepp, R. A. (2005). Teacher's perceptions on the Roles on Educational Technology. Educational Technology \& Society, 8(2), 102-106.

Marija Ovsenik received her Master's degree in organizational sciences in 1985, and her doctorate in social policy and social management in 1990. In 2002, she became full professor at University of Ljubljana, Faculty of Social Work. She managed the TEMPUS project which resulted in the educational program Management in Social Work on undergraduate and graduate level. She also taught at University of Maribor and at University of Primorska where she was dean of the Faculty of Tourism for four years. Currently she teaches and manages the program Social Gerontology at Alma Mater Europaea, European Centre Maribor, and teaches at Faculty of Organizational Studies in Novo mesto. She published 9 books and several of articles in journals indexed in SCI, Scopus, CSA, and mentored 27 doctoral theses, over 70 master thesis and several hundred diploma assignments. She participated in preparation of several higher education curricula; 11 of them have received accreditation. She managed a Leonardo da Vinci project and participated in international projects with University of Goetheborg. She gave invited speeches at University of Goetheborg, Case Western Reserve in Cleveland, USA, Lyn University in Boca Raton, USA and St. Thomas University in Miami USA. In 2013, she obtained her second doctorate in quality management from the Faculty of Organizational Studies in Novo mesto. 